\title{
Experimental model of smoking and simulation of reflux with acid and pepsin in rats ${ }^{1}$
}

\author{
Modelo experimental de tabagismo e simulação de refluxo com ácido e pepsina em ratos
}

\author{
José Hélio Zen Junior", André Del Negro"I, José Alexandre Colli Neto"II, Marina Rachel Araujo ${ }^{\mathrm{IV}}$, Albina Maria Altemaniv, \\ Nelson Adami Andreollo ${ }^{\mathrm{VI}}$ \\ IGraduate student, Faculty of Medical Sciences, UNICAMP, Campinas-SP, Brazil. Conception and design. Tutor: Nelson Adami Andreollo.

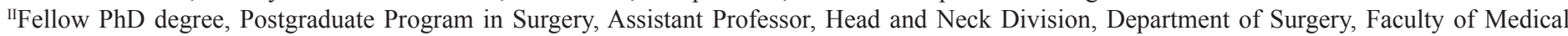 \\ Sciences, UNICAMP, Campinas-SP, Brazil. Supervisor, conception and design.

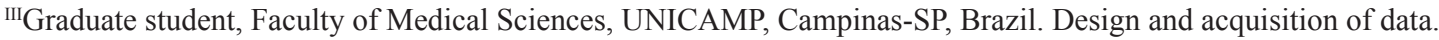

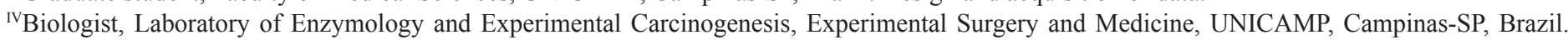 \\ Design and acquisition of data. \\ ${ }^{\mathrm{v} F u l l}$ Professor, Pathology Department, Faculty of Medical Sciences, UNICAMP, Campinas-SP, Brazil. Acquisition of data, analysis and interpretation, \\ histopathogical studies. \\ ${ }^{\mathrm{V}}$ Full Professor, Digestive Disease Division, Department of Surgery, Faculty of Medical Sciences, UNICAMP, Campinas-SP, Brazil. Supervisor, \\ conception and design.
}

\begin{abstract}
PURPOSE: To develop experimental models to evaluate the effects of hydrochloric acid associated with the pepsin instilled in the mucosa of the upper esophagus and the esophagogastric junction of young male rats Wistar, simulating injury caused by gastroesophageal reflux on the mucosa of aero-digestive tract in humans as well as the action of the risk exposure of mucosa to cigarette smoke.

METHODS: Fifty young male Wistar rats divided in 5 groups with 10 animals each one, respectively simulating pharyngo-laryngeal reflux and gastroesophageal reflux, pharyngo-laryngeal reflux and smoking, smoking only, gastroesophageal reflux and control group. RESULTS: The histopathologic studies no recorded neoplasias, only mild changes and no significant alterations. The hemo-oximetry (carboxyhemoglobin and methemoglobim) and $\mathrm{CO} 2$ concentration confirm that the animals were submitted to high intensity of exposure to carcinogens in tobacco and its derivatives.
\end{abstract}

CONCLUSION: The experimental models were highly efficient, practical, easy to use and economical and can be employed in other similar studies to determine the harmful effects by smoking and reflux.

Key words: Smoking. Hydrochloric Acid. Pepsin. Gastroesophageal Reflux. Rats.

\section{RESUMO}

OBJETIVO: Desenvolver modelos experimentais para avaliar os efeitos do ácido clorídrico associado a pepsina, instilados na mucosa da parte superior do esôfago e da junção esofagogástrica de jovens ratos Wistar, simulando lesão causada por refluxo gastroesofágico na mucosa do trato aero-digestivo em humanos, bem como a ação da exposição ao risco de mucosa, como a fumaça de cigarro.

MÉTODOS: Cinqüenta jovens ratos Wistar divididos em cinco grupos com 10 animais cada um, respectivamente, simulando o refluxo faringo-laríngeo e refluxo gastroesofágico, refluxo faringo-laríngeo e tabagismo, tabagismo só, refluxo gastroesofágico e grupo controle. RESULTADOS: os estudos histopatológicos não registraram neoplasias, apenas leves alterações e não significativas. O hemo-oximetria (carboxiemoglobina e metemoglobina) e concentração de $\mathrm{CO} 2$ corroboram que os animais foram submetidos a alta intensidade de exposição a substâncias cancerígenas do tabaco e seus derivados.

CONCLUSÃO: os modelos experimentais desenvolvidos foram altamente eficientes, práticos, fáceis de usar e econômicos podendo ser empregados em outros estudos semelhantes para determinar os efeitos prejudiciais causados pelo tabagismo e refluxo.

Descritores: Tabagismo. Ácido Clorídrico. Pepsina. Refluxo Gastroesofágico. Ratos. 


\section{Introduction}

The association of smoking and drinking with malignancies of the upper aero-digestive tract is well known for years. The most common sites of tumor involvement are the oral cavity, larynx and pharynx. The larynx is affected in $25 \%$ of cases of malignant neoplasms of head and neck, the throat being the most commonly involved. Incidence rates vary according to population, although statistics are unanimous in pointing to the male population as being more often affected than the female ${ }^{1-3}$.

Approximately $90 \%$ of tumors in the region are of the squamous cell carcinoma (SCC). Smokers are seven times higher risk of developing oral cancer, heavy drinkers are five times greater risk, those who smoke and drink heavily have a risk increased by 30 times. Mucosal cells chronically exposed tend to develop genetic abnormalities, activating protooncogenes and inactivate tumor suppressor genes. The cell cycle becomes abnormal and the mucosal cells develop genetic instability and accelerated cell cycle with an inability to repair and apoptosis, evolving into cell clones pre-malignant and malignant ${ }^{1-4}$.

However, approximately $5 \%$ of patients with squamous cell carcinoma of the upper aero-digestive tract are not smoked or drank ${ }^{5}$. Recently other risk factors have attracted increasing interest in studying the pathogenesis of this tumor in this region, particularly gastroesophageal reflux and pharyngo-laryngeal reflux, which have as mucosal irritant the hydrochloric acid. Experimental studies have confirmed this hypothesis, however, preliminary experimental research simulating pharyngoesophageal reflux showed no carcinogenic action of reflux alone on the mucosa of the upper aero-digestive tract ${ }^{4,6-9}$.

The aim of this study is to develop experimental models to evaluate the carcinogenic action of hydrochloric acid associated with the pepsin, when instilled in the mucosa of the upper esophagus and the esophagogastric junction of young male rats Wistar, simulating injury caused by gastroesophageal reflux on the mucosa of aero-digestive tract in humans as well as the action of the risk exposure of mucosa to cigarette smoke.

\section{Methods}

Fifty young male Wistar rats weighing between 300 and $400 \mathrm{~g}$, chosen at random were studied. The animals were kept in cages for the common species, lined with wood shavings and kept in the animal colony at the Experimental Surgery and Medicine Division. The research was approved by the Ethics Committee of Animal Experiments, Institute of Biology Protocol (1441-1/2008).
The solution used for simulating the pharyngo-laryngeal reflux and gastro-esophageal reflux contained $0.1 \mathrm{~N}$ hydrochloric acid plus pepsin at a dilution of $1 \mathrm{mg}$ in $1 \mathrm{ml}$ of distilled water. Cigarettes used contained the following specifications: 10mg tar per cigarette, nicotine $0.8 \mathrm{mg} /$ cigarette; CO $10 \mathrm{mg} /$ cigarette. Water was offered ad libitum for all animals, each one receiving a specific number, marked with hair dye in the hair and body, were included randomly in one of five groups:

Group I - Ten animals submitted to daily application of the solution of hydrochloric acid and pepsin directly on the cervical esophageal mucosa;

Group II - Ten animals submitted to daily application of the solution of hydrochloric acid and pepsin directly on the mucosa of the cervical esophagus, and inhalation exposure to cigarette smoke in the exposure chamber;

Group III - Ten animals submitted to daily exposure to cigarette smoke inhalation in a chamber exposure;

Group IV - Ten animals submitted to daily application of the solution of hydrochloric acid and pepsin directly on the mucosa of the esophagogastric junction;

Group V - The control animals submitted to daily application of filtered water directly on the esophageal mucosa.

The application of the solutions on the esophageal mucosa was performed with a number one soft brush, using atraumatic retractors to expose the esophageal mucosa of the rats. A brush marked with yellow exclusive application of acid-pepsin mixture, and a brush marked in blue for exclusive application of the filtered water. The application on the distal esophagus and esophagogastric junction took place by gavage using atraumatic cannulation. There was no need for anesthesia because the procedure did not cause major discomfort to the animals.

Smoke exposure was performed in a chamber described by Wright et al. ${ }^{10}$ and modified by Biselli ${ }^{11}$ (Figure 1) consists of a sealed container to pack animals, mated to a laminar flow system with compressed air. The particles were accelerated in a compressed air system with laminar flow pressure drop, flowdependent and acceleration. By reducing the transverse diameter of the tube using a pipette filed, the compressed air was accelerated (steadily, but the air particles passing through the pipette tip acquired a higher speed). When the pressure at this point suffered 
a fall below atmospheric pressure to produce the desired effect: aspiration of cigarette smoke on the other end of the system.

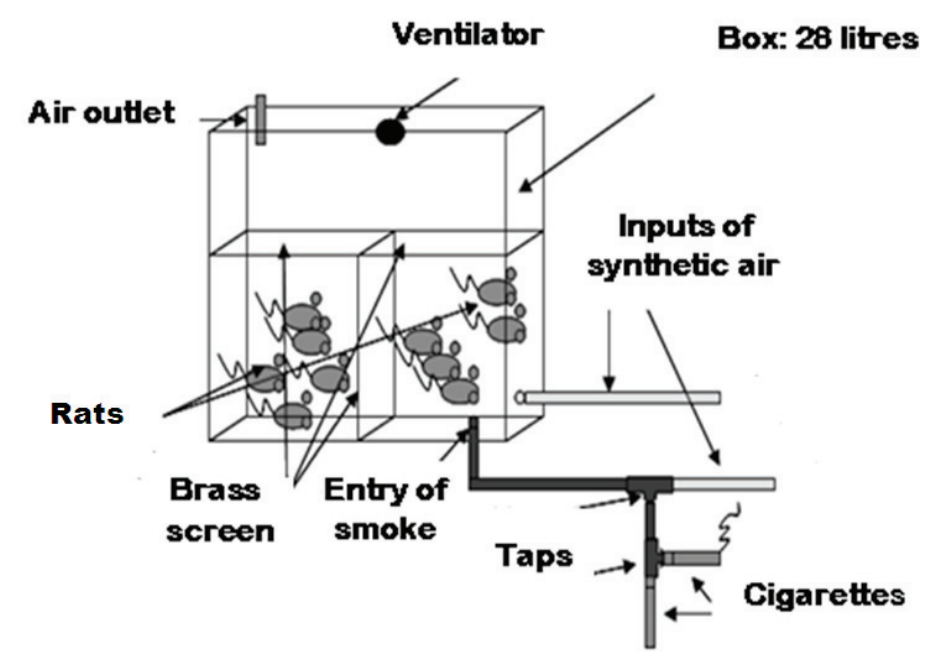

FIGURE 1 - Chamber of exposure do cigarette smoke (Bizelli $\left.{ }^{11}\right)$.

A tank of compressed air to pressurize the chamber through an air duct was connected to the above system to obtain a greater amount of gas produced by burning cigarettes. And inside the chamber were placed cigarettes already lit with the end of the filter attached to another air conduit which leads directly to the smoke exposure chamber, thus obtaining a significant increase in the amount of smoke produced and inhaled by animals. The animals of the groups II and III were submitted to daily applications of the solution of hydrochloric acid and pepsin and smoke exposure ( 8 cigarettes per day) for six months, a period considered long enough to cause changes in the mucosa, because on average a months of the animal life is approximately five years of the human life ${ }^{12}$. In the chamber of smoke exposure was also made the analysis the number of $\mathrm{CO}$ particles with the equipament ToxiPro $^{\circledR}$ (Biosystems). During the observation period the animals were fed with standard diet and their weights were monitored monthly.

The hemo-oximetry of the animals was performed in two times of the study, to evaluate the effectiveness of the exposure chamber, using the equipment Radiometer Oximeter model OSM 3.

At the end of the study the rats were euthanized by prolonged intravenous anesthesia with thiopental in lethal dose of $2 \mathrm{ml} / \mathrm{kg} /$ weight. The organs for histopathological studies were obtained from dissection of the mucosa at risk, removing them completely, that is similar to the surgical procedure performed in humans. Were fixed in formalin for 24 hours and then stored in $70 \%$ alcohol solution and fixed in paraffin blocks. The sections were prepared on slides and stained with hematoxylin and eosin.
Statistical analysis employing chi-square test were applied and results were considered significant at $5 \%(\mathrm{p}<0.05)$.

\section{Results}

\section{Weight of animals}

No significant changes were observed in animal weights between groups, which ranged from 300 to $460 \mathrm{~g}$, and all of which gained weight during the experiment.

\section{Hemo-oximetry}

The measurement was performed in two animals exposed to smoke and one animal control, and those exposed to smoke were assessed in two stages: 5 minutes and 10 minutes after exposure. The items analysed were: Hemoglobin $(\mathrm{Hb})$, oxyhemoglobin (HBO2), carboxyhemoglobin (HbCO), methemoglobin (MetHb), Total Oxygen (O2 total), 5 minutes of exposure (5') and 10 minutes of exposure (10'), as follows (Table 1):

TABLE 1 - Hemo-oximetry of animals exposed to smoke at 5 and 10 minutes, and animal control.

\begin{tabular}{cccccc}
\hline & $\mathrm{Hb}(\mathrm{g} / \mathrm{dl})$ & $\mathrm{HbO} 2$ & $\mathrm{HbCO}$ & $\mathrm{MetHb}$ & $\mathrm{O} 2$ total \\
\hline Rat $1-5$ & 18.9 & 58.1 & 0.2 & 0.8 & 15.1 \\
\hline Rat $1-10$ & 18.9 & 58.6 & 6.8 & 1.4 & 15.2 \\
\hline Rat 2 -5' & 19.7 & 60.5 & 0.2 & 0.7 & 15.2 \\
\hline Rat 2 - 10' & 19.7 & 60.4 & 7.1 & 1.5 & 15.4 \\
\hline Control & 19.8 & 45.9 & 0.4 & 0.6 & 14.4 \\
\hline
\end{tabular}

There was no variation in the rate of total hemoglobin and oxygen ( $\mathrm{p}>0.05)$, but oxyhemoglobin, carboxyhemoglobin, methemoglobin had a variation. The hemoglobin was elevated at 5 and 10 minutes of smoke exposure compared to control animals $(p<0.005)$. The values of carboxyhemoglobin and methemoglobin levels increase significantly compared to control after 10 minutes of exposure $(\mathrm{p}<0.05)$, and the carboxyhemoglobin suffered very high elevation.

\section{CO2 concentration}

The CO2 concentration inside the exposure chamber after firing the third cigarette, measured with the apparatus above was performed daily for two weeks, obtaining as a result always far greater than 999 parts per million at all times of measurement (and so high above the threshold that the equipment showed the message "out of limit"). Therefore, the concentration of $\mathrm{CO} 2$ resulting from burning cigarettes into the exposure chamber where the animals were located, were positive and significant. 


\section{Histopathologic analysis}

The histopathologic analysis of samples obtained from animals showed:

Group I - Laryngo-esophageal reflux - two animals with an area of dysplasia with mild inflammatory infiltrate;

Group II - Laryngo-esophageal reflux associated with smoking - two animals with areas of focal epithelial hyperplasia and two animals with an area of hyperplasia of the basal layer

Group III - Only smoking - No changes were found in the mucosa in a study

Group IV - Only gastroesophagical reflux - two animals with mild focal epithelial hyperplasia

Group V - Control with simulated reflux with water - No changes were found

Therefore, no neoplastic lesions were recorded in both experiments. During the experiment three animals died inside the exposure chamber (one in Group II and two of Group III).

\section{Discussion}

The tobacco contains more than thirty known carcinogens, mostly composed of polycyclic aromatic hydrocarbons and nitrosamines. The relative risk of developing laryngeal cancer among smokers and nonsmokers is 15.5 times. Stop smoking reduces the risk of neoplastic and pre-neoplastic lesions, reaching the level of patients who never smoked after fifteen years ${ }^{1-3}$.

There are few experimental models of exposure to cigarette smoke, although most of them being used for mices. The Wistar and Sprague-Dawley rats, rabbits, dogs and guinea pigs have already been used in studies with different exposure chambers and different protocols, although ideal model has not exist. D'Agostini et al. ${ }^{13}$ studied the protective effect of N-acetylcysteine on Sprague-Dawley rats exposed to cigarette smoke exposure machine in TE-10 (Teague Enterprises, Davis, CA).

Shapiro ${ }^{14}$ proposed a sealed chamber with high exposure to tobacco content for the study of chronic obstructive pulmonary disease in mice. His model was used and modified by Biselli ${ }^{11}$, who studied the effect of exposure to cigarette smoke and diesel oil residue in the lungs of mice. This research employed this experimental model.

The gastroesophageal reflux disease (GERD) is highly prevalent in the population geral ${ }^{15}$. Reflux pharyngolaryngeal understands the gastroesophageal reflux that is not confined to the lower esophagus, esophageal sphincter reaching the top, which can cause numerous disturbances in the pharynx and larynx. The occurrence of symptoms related to this reflux in clinical practice is estimated at 40 to $10 \%{ }^{16-18}$. Helicobacter pylori has also been studied as a possible agent involved in the genesis of these symptoms ${ }^{19}$. Moreover, participation of nitrites, nitrates and nitrosamines in the genesis of tumors of head and neck and esophageal has been widely studied in recent years ${ }^{20,21}$. One of the first publications on laryngeal epithelial changes due to reflux was reported that Cherry and Margulies ${ }^{22}$ contact ulcers on the posterior third of the vocal cords of three patients not explained by vocal abuse.

Koufman $^{2}$ studied experimentally the mechanisms of the deleterious effects of the hydrochloric acid associated to pepsin in the subglottic mucosa of $20 \mathrm{dogs}$ divided into three groups, with applications of saline, only pepsin, neutralized acid and sodium hydroxide (control group), $0.1 \mathrm{~N}$ hydrochloric acid and mixture of $0.1 \mathrm{~N}$ hydrochloric acid with pepsin at a dilution of $0.3 \mathrm{mg} / \mathrm{ml}$. The author observed that the group submitted to application of hydrochloric acid was higher latency for healing of the inflammatory process in the control group and there was no healing in the group subjected to acid and pepsin mixture.

Adams et al..$^{23}$ studied the tumorigenic action of hydrochloric acid with or without pepsin and the carcinogen dimethyl-benzanthracene in oral mucosa of hamsters. They found that the combined action of hydrochloric acid with pepsin promoted the development of neoplastic lesions larger than the control group, concluding that these animals are susceptible to these solutions.

Goldberg et al. ${ }^{24}$ reported on research using cats greater tissue damage in esophageal mucosa submitted to application of the mixture with higher concentrations of acid and pepsin, without noticing precancerous changes. Lillemoe et al..$^{25}$ found that rabbits using pepsin at acid $\mathrm{pH}$ is more irritating effect on the esophageal mucosa that trypsin or bile acid alone, nor are neoplastic changes.

This study aimed to develop models for experimental carcinogenesis in the gastroesophageal mucosa exposed to acid and pepsin associated with cigarette smoke. Analysing the results we can deduce that the weight of the animals proved to be up in isolated analysis of each specimen, showing no changes, and showing that did not interfere with the feeding of animals.

The hemo-oximetry performed on two occasions during the follow-up possible evidence for analysis of carboxyhemoglobin and methemoglobin that the system was effective to provide the animals inhale the substances derived from the burning cigarette inside the exposure chamber. Moreover, it was shown that the dose was strongly linked to exposure time. Therefore, the simulation 
system of smoking was very efficient, with the critical time of exposure. Poising by $\mathrm{CO}$ and $\mathrm{CO} 2$ was so high that it caused loss of 3 animals at the beginning of the experiment.

The $\mathrm{CO} 2$ concentration was also very high and this other factor that corroborates the fact that the high intensity of exposure of animals to carcinogenic substances in tobacco and its derivatives. However, this high exposure to $\mathrm{CO} 2$ is associated to risk of loss of animals by acute poisoning and suffocation, and a discussion point for the study of alternatives that reduce its partial pressure inside the exposure chamber.

The histopathologic examination showed mild changes and no significant, however must be taken into account due to the small number of animals, further experiments are needed in the future.

\section{Conclusion}

The experimental models were highly efficient, practical, easy to use and economical and can be employed in other similar studies to determine the harmful effects by smoking and reflux.

\section{References}

1. De Stefani E, Correa P, Oreggia F, Leiva J, Rivero S, Fernandez G, Deneo-Pellegrini H, Zavala D, Fontham E. Risk factors for laryngeal cancer. Cancer. 198715;60(12):3087-91.

2. Koufman JA, Burke AJ. The etiology and pathogenesis of laryngeal carcinoma. Otolaryngol Clin North Am. 1997;30(1):1-19.

3. Del Negro A, Araújo MR, Tincani AJ, Meirelles L, Martins AS, Andreollo NA. Experimental carcinogenesis on the oropharyngeal mucosa of rats with hydrochloric acid, sodium nitrate and pepsin. Acta Cir Bras. 2008;23(4):337-42.

4. Copper MP, Smit CF, Stanojcic LD, Devriese PP, Schouwenburg $\mathrm{PF}$, Mathus-Vliegen LMH. High incidence of laryngo-pharyngeal reflux in patients with head and neck cancer. Laryngoscope. 2000;110:1007-11.

5. Wight R, Paleri V, Arullendran P. Current theories for the development of nonsmoking and nondrinking laryngeal carcinoma. Curr Opin Otolaryngol Head Neck Surg. 2003;11(2):73-7.

6. Galli J, Cammarota G, Calo L, Agostino S, D'Ugo D, Cianci R, Almadori G. The role of acid and alkaline reflux in laryngeal squamous cell carcinoma. Laryngoscope. 2002;112(10):1861-5.

7. Bacciu A, Mercante $G$, Ingegnoli A, Bacciu S, Ferri T. Reflux esophagitis as a possible risk factor in the development of pharyngolaryngeal squamous cell carcinoma. Tumori. 2003;89(5):485-7.

8. Ozlugedik S, Yorulmaz I, Gokcan K. Is laryngopharyngeal reflux an important risk factor in the development of laryngeal carcinoma? Eur Arch Otorhiolaryngol. 2006;263(4):339-43.

9. El-Serag HB, Hepworth EJ, Lee P, Sonnenberg A. Gastroesophageal reflux disease is a risk factor for laryngeal and pharyngeal cancer. Am J Gastroenterol. 2001;96(7):2013-8.

10. Wright JL, Churg A. Cigarette smoke causes physiologic and morphologic changes of emphysema in the guinea pig. Am Rev Respir Dis. 1990;142(6):1422-8.

11. Biselli PJC. Effect of exposure to cigarette smoke and diesel oil residue in the lungs of mice C57/B16 9 (Doctoral thesis). University of Sao Paulo: Faculty of Medicine; 2008.

12. Quinn R. Comparing rat's to human's age: how old is my rat in people years? Nutrition. 2005;21:777-7.

13. D'Agostini F, Balansky RM, Izzotti A, Lubet RA, Kelloff GJ, De Flora S. Modulation of apoptosis by cigarette smoke and cancer chemopreventive agents in the respiratory tract of rats. Carcinogenesis. 2001;22(3):375-80.

14. Shapiro SD. Animal models for COPD. Chest. 2000;117:223S-7.

15. Andreollo NA, Lopes LR, Coelho-Neto JS. Gastroesophageal reflux disease: what is the effectiveness of diagnostic tests? ABCD Arq Bras Cir Dig. 2010;23(1):6-10.

16. Koufman JA. Laryngopharyngeal reflux is different from classic gastroesophageal reflux disease. Ear Nose Throat J. 2002;81(9 Suppl 2):7-9.

17. Bulmer DM, Ali MS, Brownlee IA, Dettmar DW, Pearson JP. Laryngeal mucosa: its susceptibility to acid and pepsin. Laryngoscope. 2010;120(4):777-82.

18. Francis DO, Maynard C, Weymuller EA, Reiber G, Merati AL, Yueh B. Reevaluation of gastroesophageal reflux disease as a risk factor for laryngeal. Cancer. 2011;121:102-5.

19. Nurgalieva ZZ, Graham DY, Dahlstrom KR, Wei Q, Sturgis EM. A pilot study of Helicobacter pylori infection and risk of laryngopharyngeal cancer. Head Neck. 2005;27(1):22-7.

20. Winter JW, Paterson S, Scobie G, Preston T, McColl KE. $\mathrm{N}$-nitrosamine generation from ingested nitrate via nitric oxide in subjects with and without gastroesophageal reflux. Gastroenterology. 2007;133(1):164-74.

21. Modena SF, Meirelles LR, Araújo MR, Lopes LR, Andreollo NA. Role of nitrites in the genesis of adenocarcinoma associated with Barrett's esophagus. In Vivo. 2009;23(6):919-23.

22. Cherry J, Margulies SI. Contact ulcer of the larynx. Laryngoscope. 1968:78(11):1937-40

23. Adams J, Heintz P, Gross N, Andersen P, Everts E, Wax M, Cohen J. Acid/pepsin promotion of carcinogenesis in the hamster cheek pouch. Arch Otolaryngol Head Neck Surg. 2000;126:405-9.

24. Goldberg HI, Dodds WJ, Gee S, Montgomery C, Zboralske FF. Role of acid and pepsin in acute experimental esophagitis. Gastroenterology. 1969;56(2):223-30.

25. Lillemoe KD, Johnson LF, Harmon JW. Role of components of the gastroduodenal contents in experimental acid esophagitis. Surgery. 1982;92(2):276-84.

\section{Acknowledgments}

Thanks to Doctors Alfio José Tincani and Antonio Santos Martins.

\section{Correspondence:}

Nelson Adami Andreollo

UNICAMP - Depto Cirurgia

Rua Alexander Fleming, 181

13.083-970 Campinas - SP Brasil

Tel.: (55 19)3521-9448

nandreollo@hotmail.com

Received: August 17, 2011

Review: October 18, 2011

Accepted: November 21, 2011

Conflict of interest: none

Financial source: FAPESP

${ }^{1}$ Research performed at Laboratory of Enzymology and Experimental Carcinogenesis, Experimental Surgery and Medicine Division, Faculty of Medical Sciences, State University of Campinas (UNICAMP), Sao Paulo, Brazil. 